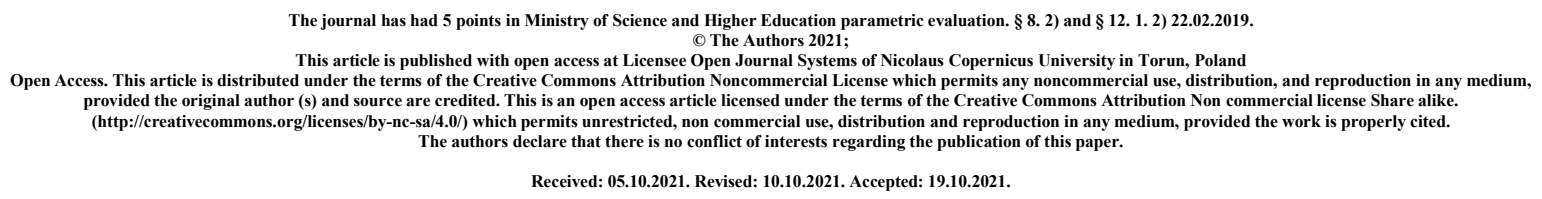

Epidemiology of colorectal cancer (C18-C21) in Poland

Epidemiologia raka jelita grubego (C18-C21) w Polsce

\title{
Zuzanna Jaroszyńska
}

E-mail address: zu.jaroszynska@gmail.com

ORCID iD: https://orcid.org/0000-0003-2349-179X

Affiliation: Public Health graduate - Poznan University of Medical Sciences, Poznan, Poland

\section{Katarzyna Wiśniewska}

E-mail address: kwisniewska@ump.edu.pl

ORCID iD: https://orcid.org/0000-0003-0025-1398

Affiliation: Department of Preventive Medicine, Epidemiology Unit, Poznan University of

Medical Sciences, Poznan, Poland

\section{Streszczenie}

Wprowadzenie i cel: Rak jelita grubego (C18-C21) jest jednym z najczęściej występujących nowotworów złośliwych w polskiej populacji. Celem niniejszej pracy była analiza sytuacji epidemiologicznej raka jelita grubego w Polsce, której dokonano na podstawie danych epidemiologicznych, opublikowanych przez Krajowy Rejestr Nowotworów, Narodowy Instytut Onkologii im. Marii Skłodowskiej-Curie - Państwowy Instytut Badawczy oraz ECIS European Cancer Information System.

Opis stanu wiedzy: Rak jelita grubego był w Polsce w 2018 roku trzecim co do częstości występowania nowotworem złośliwym, na który zapadają mężczyźni i drugim najczęściej diagnozowanym nowotworem złośliwym $u$ kobiet. $W$ tym samym roku $w$ Polsce zarejestrowano niemal 12,5 tys. zgonów z powodu raka jelita grubego. Nowotwór ten stanowił wówczas drugą wśród mężczyzn i trzecią wśród kobiet najczęstszą przyczynę zgonów z powodu nowotworów złośliwych. Pod względem wskaźników 5 letnich przeżyć dla pacjentów chorych na raka jelita grubego, mimo obserwowanej na przestrzeni lat poprawy, Polska wciąż zajmuje jedno z ostatnich miejsc w Europie.

Wnioski: Rak jelita grubego, ze względu na rozpowszechnienie, stanowi poważny problem zdrowotny polskiego społeczeństwa. Skala zachorowań i zgonów $z$ powodu tych nowotworów, mimo rozwijającej się wiedzy medycznej oraz poprawy dostępności do nowoczesnych metod diagnostycznych i terapeutycznych, wciąż jest niepokojąca. Istnieje pilna potrzeba zintensyfikowania działań w obszarze profilaktyki przeciwnowotworowej na poziomie populacyjnym. 
Słowa kluczowe: rak jelita grubego; epidemiologia; zdrowie publiczne

\section{Summary}

Introduction and purpose: Colorectal cancer $(\mathrm{C} 18-\mathrm{C} 21)$ is one of the most common malignant neoplasms in the Polish population. The aim of this study was to analyze the epidemiological situation of colorectal cancer in Poland, based on epidemiological data published by Polish National Cancer Registry, the Maria Sklodowska-Curie National Research Institute of Oncology and ECIS - European Cancer Information System.

A brief description of the state of knowledge: In 2018, colorectal cancer was the third most common malignant neoplasm of men in Poland and the second most frequently diagnosed malignant neoplasm in women. In the same year, almost 12,500 deaths due to colorectal cancer were registered in Poland. At that time, this cancer was the second most common cause of death from malignant neoplasms among men and the third among women. In terms of 5-year survival rates for patients with colorectal cancer, despite the improvement observed over the years, Poland is still one of the last places in Europe.

Conclusions: Colorectal cancer, due to its prevalence, is a serious health problem for Polish society. The scale of morbidity and deaths from these cancers, despite the growing medical knowledge and the improved access to modern diagnostic and therapeutic methods, is still worrying. There is an urgent need to intensify activities in the area of cancer prevention at the population level.

Key words: colorectal cancer; epidemiology; public health

\section{Wprowadzenie i cel}

Nowotwory złośliwe to niezwykle istotny, wciąż narastający problem zdrowia publicznego. Stanowi on - w ujęciu globalnym - ogromne zdrowotne, społeczne, a także ekonomiczne wyzwanie współczesnego społeczeństwa [1,2].

Obserwowany w Polsce od wielu lat wzrost liczby zachorowań i zgonów z powodu nowotworów złośliwych przypisuje się zmianom, jakie nastąpiły w strukturze wiekowej ludności (większy udział osób powyżej 65 roku życia w populacji), a także zwiększonej ekspozycji populacji na czynniki kancerogenne [1-3]. W 2018 roku w Polsce zarejestrowano niemal 168 tys. nowych przypadków zachorowań na nowotwory złośliwe i stwierdzono blisko 102 tys. zgonów z tego powodu. Szacuje się, że w 2018 roku u 436 osób na każde 100 tys. polskiej populacji rozpoznano nowotwór złośliwy. Już od wielu lat nowotwory złośliwe stanowią drugą - po chorobach układu krążenia - przyczynę zgonów polskiego społeczeństwa, powodując w 2018 roku 25,9\% zgonów mężczyzn i 23,1\% zgonów kobiet [3].

Rak jelita grubego, traktowany jako nowotwór złośliwy występujący w obrębie okrężnicy, zgięcia esiczo-odbytniczego, odbytnicy i odbytu (C18-C21) jest jednym z najczęściej występujących nowotworów złośliwych w polskiej populacji. W okresie ostatnich czterech dekad liczba zachorowań na raka jelita grubego wzrosła niemal 5-krotnie u mężczyzn i ponad 3-krotnie u kobiet. W 2018 roku w Polsce zarejestrowano niemal 12,5 tys. zgonów z powodu raka jelita grubego. Nowotwór ten stanowił wówczas drugą wśród mężczyzn i trzecią wśród kobiet najczęstszą przyczynę zgonów z powodu nowotworów złośliwych. Liczba zgonów z powodu raka jelita grubego od lat 80 . XX wieku wśród polskich mężczyzn zwiększyła się ponad 3-krotnie, z kolei w populacji kobiet uległa ona podwojeniu [1,3-5].

Rak jelita grubego w większości przypadków rozwija się na podłożu łagodnych zmian nowotworowych, a proces transformacji złośliwej trwa zwykle kilkanaście lat. Długi czas 
rozwoju choroby i długoletni okres bezobjawowy sprawiają, że rak jelita grubego stanowi doskonały cel do badań przesiewowych (skriningowych). Wykrywanie zmian przednowotworowych oraz nowotworów złośliwych we wczesnym stadium zaawansowania pozwala na skuteczne leczenie, co - w skali populacyjnej - stanowi szansę na ograniczenie zachorowalności i umieralności z powodu raka jelita grubego, tym samym może przyczynić się do poprawy przeżywalności chorych [6-10].

Niestety, poziom zgłaszalności na badania przesiewowe $\mathrm{w}$ kierunku raka jelita grubego $\mathrm{w}$ Polsce jest niezwykle niski, a nowotwór ten rozpoznawany jest często dopiero w okresie znacznego zaawansowania klinicznego. Liczba rejestrowanych każdego roku zachorowań i zgonów z powodu raka jelita grubego w Polsce jest wysoka, a wskaźniki 5 letnich przeżyć chorych wciąż znacząco odbiegają od średnich wartości europejskich [7-11].

Niniejsza publikacja stanowi analizę sytuacji epidemiologicznej raka jelita grubego w Polsce, której dokonano w oparciu o dane epidemiologiczne opublikowane przez Krajowy Rejestr Nowotworów, Narodowy Instytut Onkologii im. Marii Skłodowskiej-Curie - Państwowy Instytut Badawczy oraz ECIS - European Cancer Information System.

\section{Opis stanu wiedzy}

\section{Zachorowalność}

Od lat 80. XX wieku trendy zachorowalności na raka jelita grubego w Polsce wykazywały trwale tendencję rosnącą, przy czym w 2018 roku odnotowano nieznaczny spadek standaryzowanych współczynników zachorowalności u obu płci. Szybki wzrost zachorowalności utrzymywał się wśród kobiet do połowy lat 90 . XX wieku, po czym tempo wzrostu wyraźnie zmniejszyło się. W populacji polskich mężczyzn dynamika wzrostu zachorowalności na raka jelita grubego jest zdecydowanie wyższa i nowotwór ten występuje w tej grupie znacznie częściej niż w populacji żeńskiej. W 2018 roku standaryzowany współczynnik zachorowalności na raka jelita grubego dla kobiet wynosił 17,9/100 000, z kolei dla mężczyzn 30,8/100 000 (ryc. 1) [3-5].

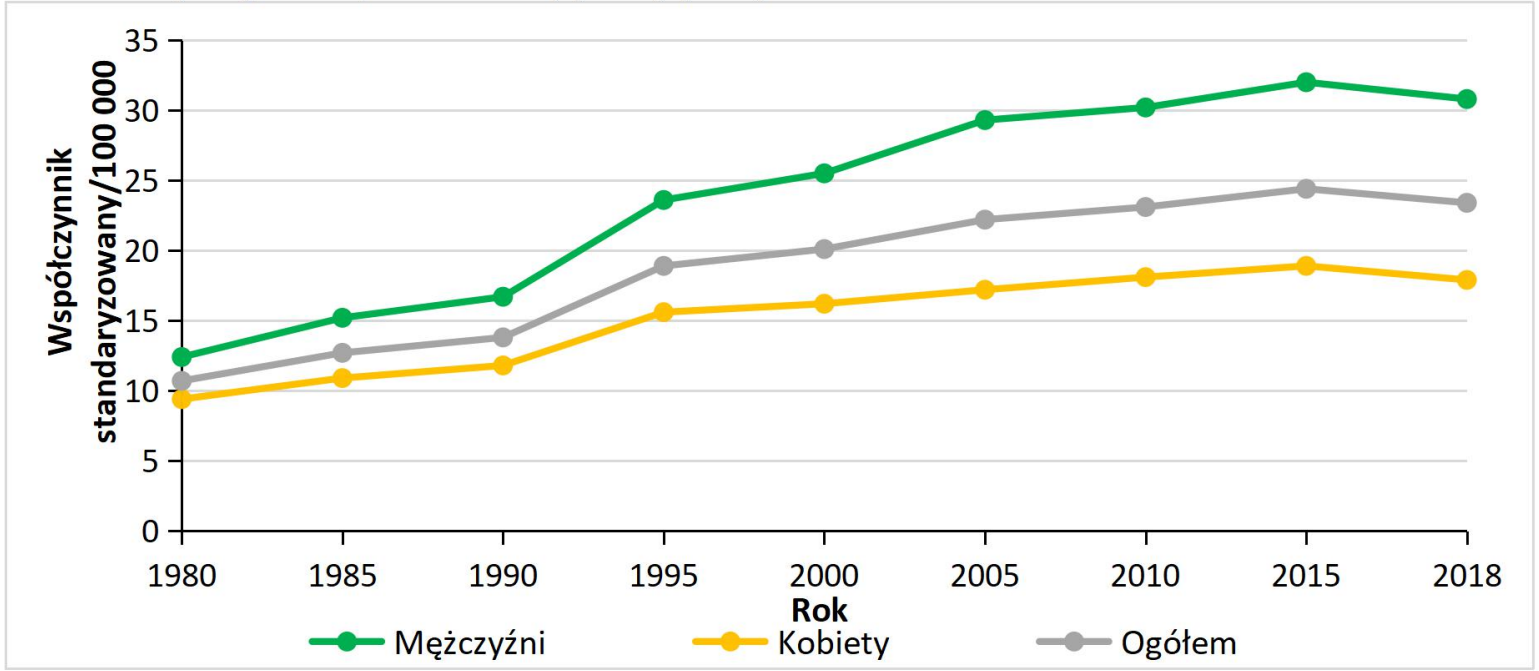

Rycina 1. Trendy zachorowalności na nowotwory złośliwe jelita grubego (C18-C21) w Polsce w latach 1980-2018 - opracowanie własne na podstawie [4,5]

Według danych Krajowego Rejestru Nowotworów w 2018 roku zarejestrowano w Polsce 18 701 nowych zachorowań na nowotwory złośliwe jelita grubego. Wśród mężczyzn odnotowano 10556 nowych przypadków, natomiast wśród kobiet 8 145. Czyniło to raka jelita grubego trzecim (po raku prostaty i raku płuca) co do częstości występowania nowotworem złośliwym, na który zapadają mężczyźni i drugim (po raku piersi) najczęściej występującym 
nowotworem złośliwym w populacji polskich kobiet (ryc. 2). W 2018 roku surowy współczynnik zachorowalności na raka jelita grubego dla mężczyzn wynosił 56,8/100 000, z kolei dla kobiet 41,1/100 $000[3,4]$.

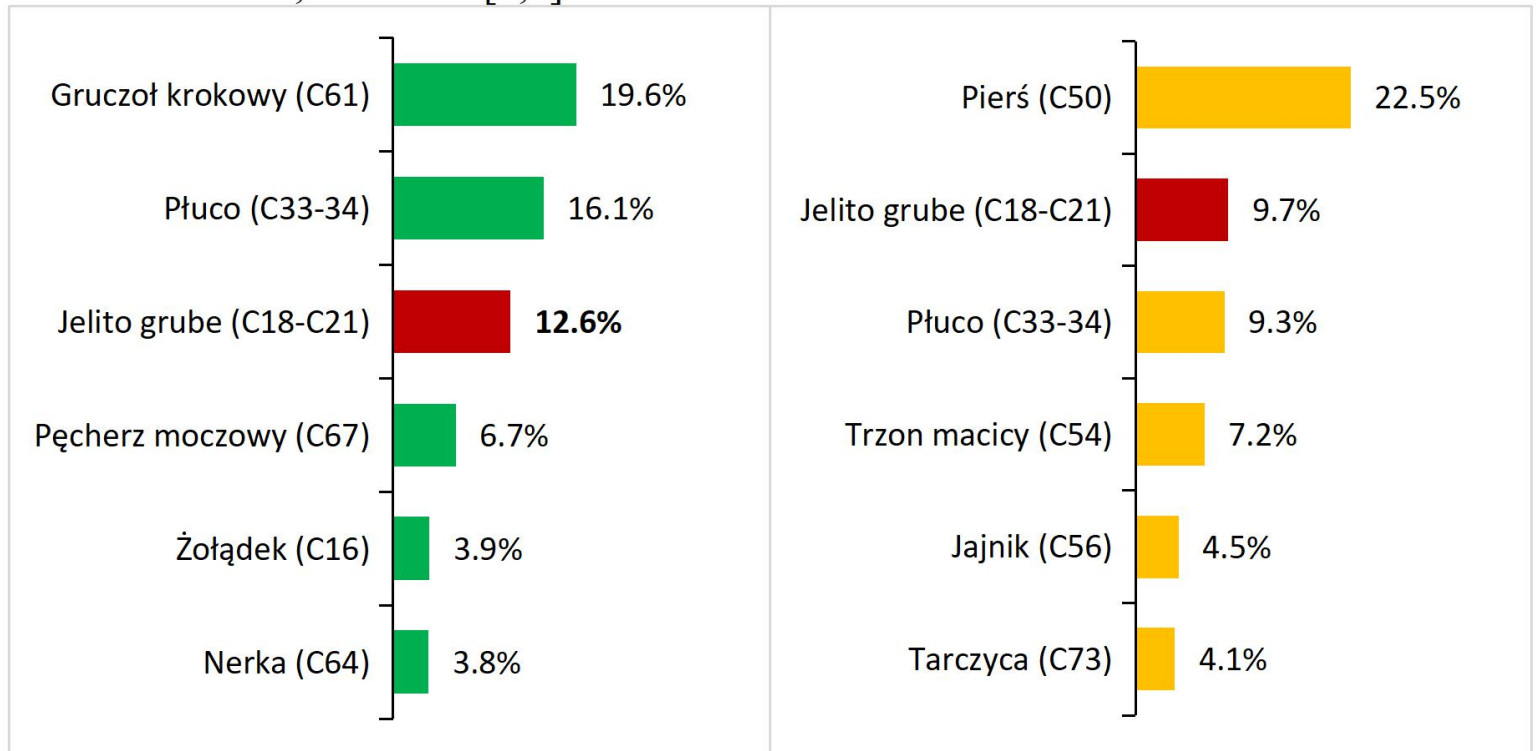

Rycina 2. Struktura najczęściej rejestrowanych zachorowań na nowotwory złośliwe u mężczyzn (po stronie lewej) i u kobiet (po stronie prawej) w Polsce w 2018 roku opracowanie wtasne na podstawie [3,4]

Większość zachorowań na nowotwory złośliwe jelita grubego, zarówno w żeńskiej, jak i męskiej populacji Polski dotyczy okrężnicy. Nowotwory złośliwe zlokalizowane w tej części stanowiły około 50-60\% wszystkich przypadków raka jelita grubego zarejestrowanych w Polsce w latach 1999-2018. Drugim co do częstości występowania w Polsce nowotworem złośliwym jelita grubego jest rak odbytnicy, stanowiący 30-40\% ogółu przypadków raka jelita grubego. Z kolei nowotwory złośliwe występujące w obrębie zgięcia esiczo-odbytniczego oraz rak odbytu i kanału odbytu stanowią łącznie około $10 \%$ rejestrowanych wśród kobiet i mężczyzn w Polsce zachorowań na raka jelita grubego (ryc. 3) [4].

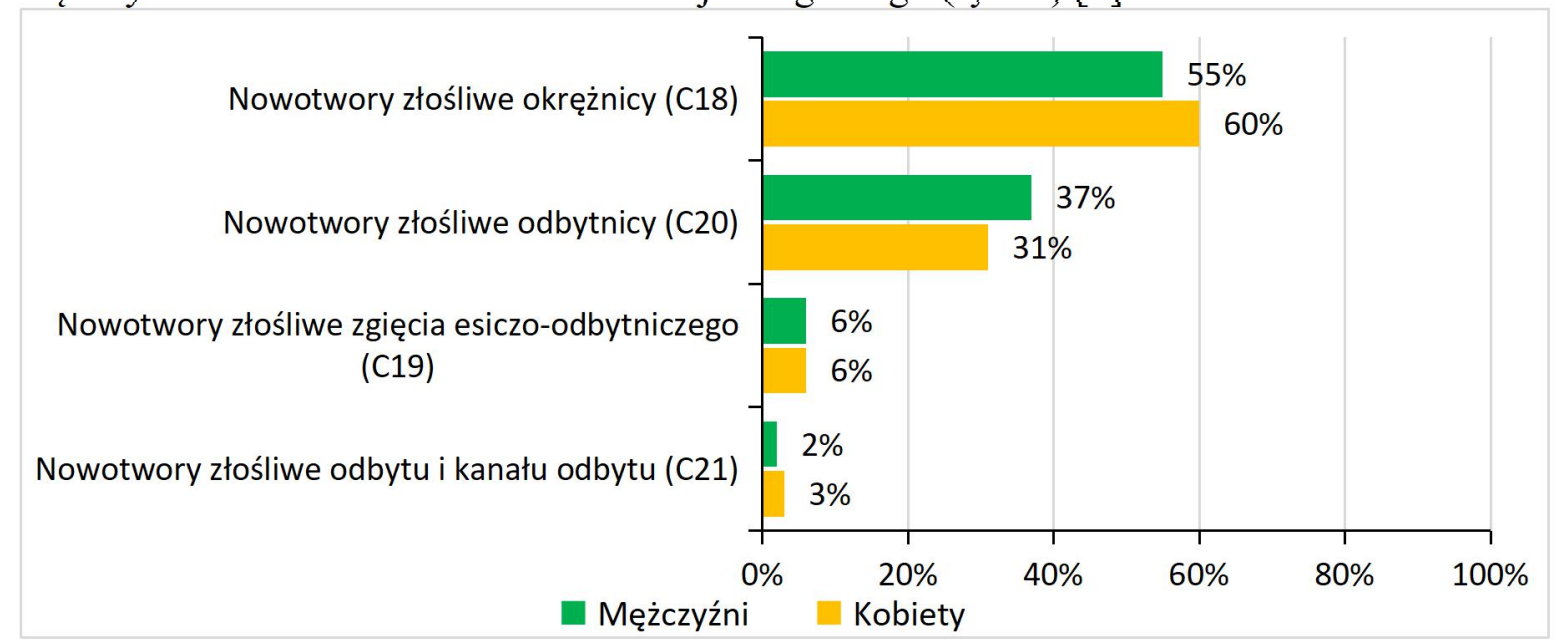

Rycina 3. Struktura zachorowań na nowotwory złośliwe jelita grubego (C18-C21) w Polsce w latach 1999-2018 - opracowanie własne na podstawie [4]

Niemal 95\% rejestrowanych w Polsce przypadków zachorowań na raka jelita grubego występuje u osób po 50 roku życia. Współczynniki zachorowalności wzrastają wraz z wiekiem od 40 roku życia u obu płci, przy czym w populacji mężczyzn ryzyko zachorowania 
jest około 1,5-2-krotnie wyższe niż w populacji kobiet. Szczyt zachorowań na nowotwory złośliwe jelita grubego, zarówno wśród mężczyzn, jak i wśród kobiet przypada na pierwszą połowę dziewiątej dekady życia, po czym częstość zachorowań maleje. W 2018 roku wartość surowych współczynników zachorowalności na raka jelita grubego dla kobiet i mężczyzn w wieku 80-84 lata wynosiły odpowiednio 174,7/100 000 i 364,6/100 000 (ryc. 4) [3-5].

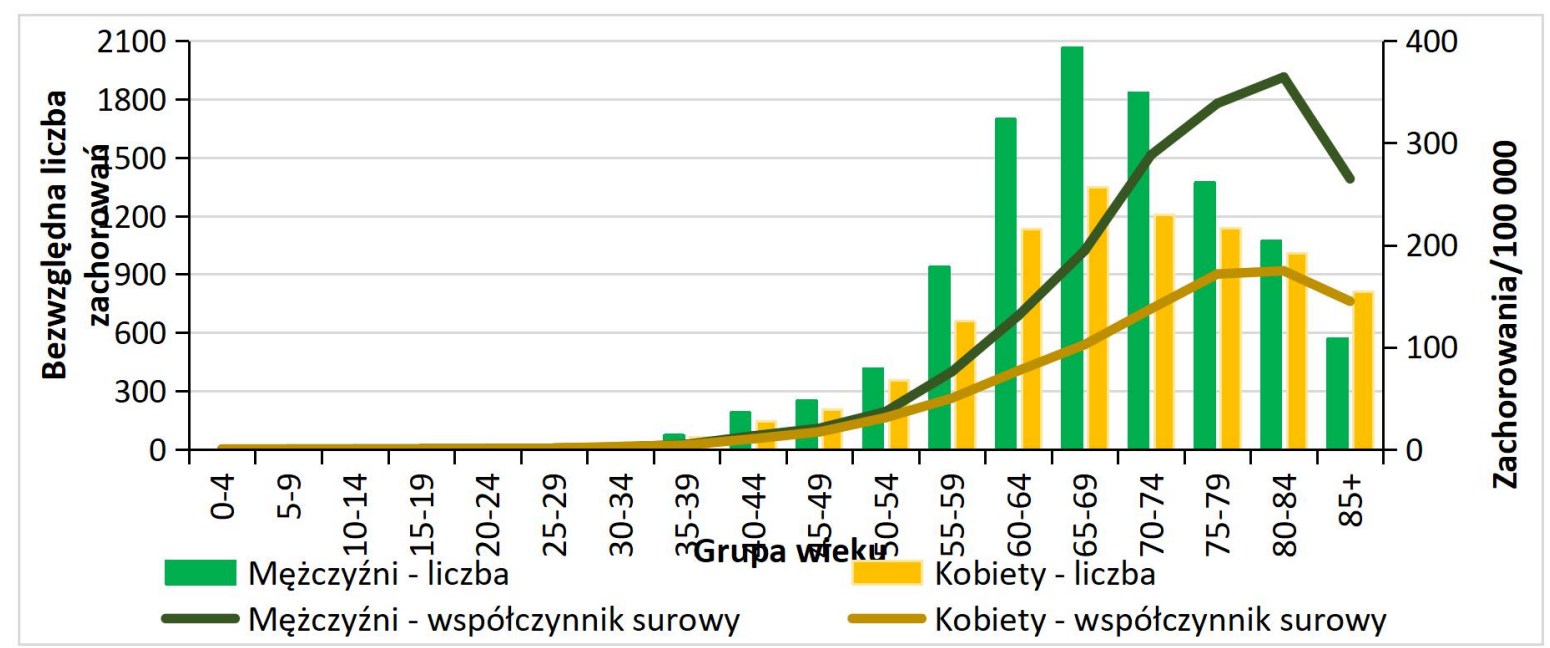

Rycina 4. Zachorowalność na nowotwory złośliwe jelita grubego (C18-C21) w 5-letnich grupach wieku w Polsce w 2018 roku (na podstawie bezwzględnej liczby zachorowań i wartości surowego współczynnika zachorowalności) - opracowanie własne na podstawie $[3,4]$

\section{Umieralność}

W okresie ostatnich czterech dekad trendy umieralności z powodu nowotworów złośliwych jelita grubego w męskiej populacji Polski utrzymywały tendencję rosnącą, przy czym w 2018 roku zaobserwowano niewielki spadek umieralności w tej grupie. Od lat 80. XX wieku wartość standaryzowanych współczynników umieralności z powodu nowotworów złośliwych jelita grubego dla mężczyzn wzrosła o ponad 60\% (11,7/100 $000 \mathrm{w} 1980$ roku vs. 19,1/100 $000 \mathrm{w} 2018 \mathrm{roku}$ ). W populacji polskich kobiet rosnący trend umieralności z powodu nowotworów złośliwych jelita grubego został zahamowany w połowie lat 90 . XX wieku i od tego czasu obserwuje się spadkową tendencję umieralności w tej grupie. Standaryzowany współczynnik umieralności z powodu nowotworów złośliwych jelita grubego dla kobiet w 1980 roku wynosił 8,8/100 000, natomiast w 2018 roku - 9,8/100 000 (ryc. 5) [3-5]. 


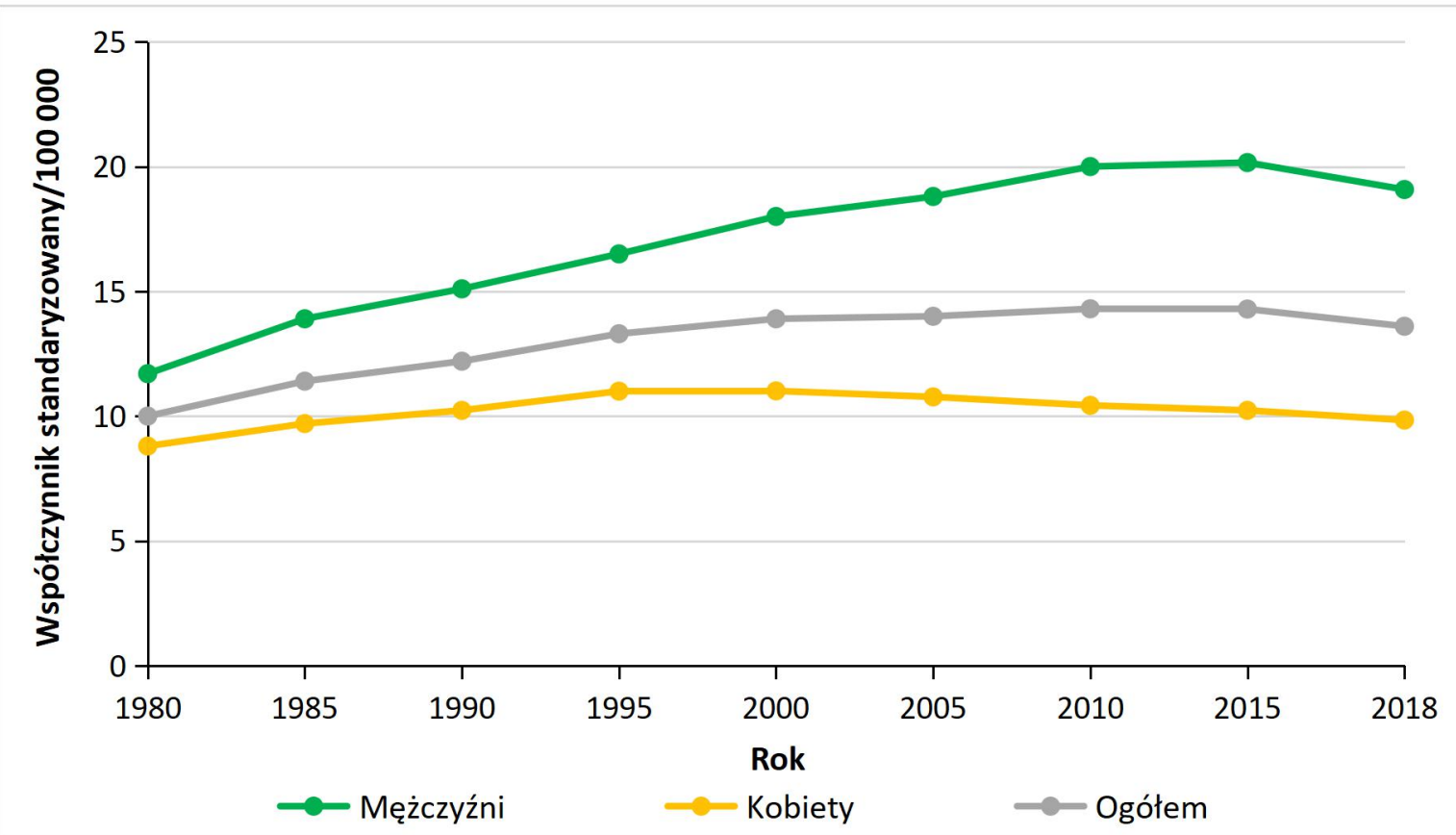

Rycina 5. Trendy umieralności z powodu nowotworów złośliwych jelita grubego (C18-C21) w Polsce w latach 1980-2018 - opracowanie własne na podstawie [4,5]

Według danych Krajowego Rejestru Nowotworów w 2018 roku odnotowano w Polsce 12434 zgony z powodu nowotworów złośliwych jelita grubego, w tym 6988 zgonów mężczyzn i 5 446 zgonów kobiet. Stanowiły one 12,6\% ogółu zgonów nowotworowych mężczyzn i 11,8\% ogółu zgonów nowotworowych kobiet. Czyniło to raka jelita grubego drugą (po raku płuca) najczęstszą przyczyną zgonów nowotworowych mężczyzn i trzecią (po raku płuca i raku piersi) najczęstszą przyczyną zgonów z powodu nowotworów złośliwych wśród kobiet (ryc. 6). Wartość surowego współczynnika umieralności z powodu nowotworów złośliwych jelita grubego w 2018 roku wynosiła dla mężczyzn 37,6/100 000, a dla kobiet 27,5/100 000 [3,4].

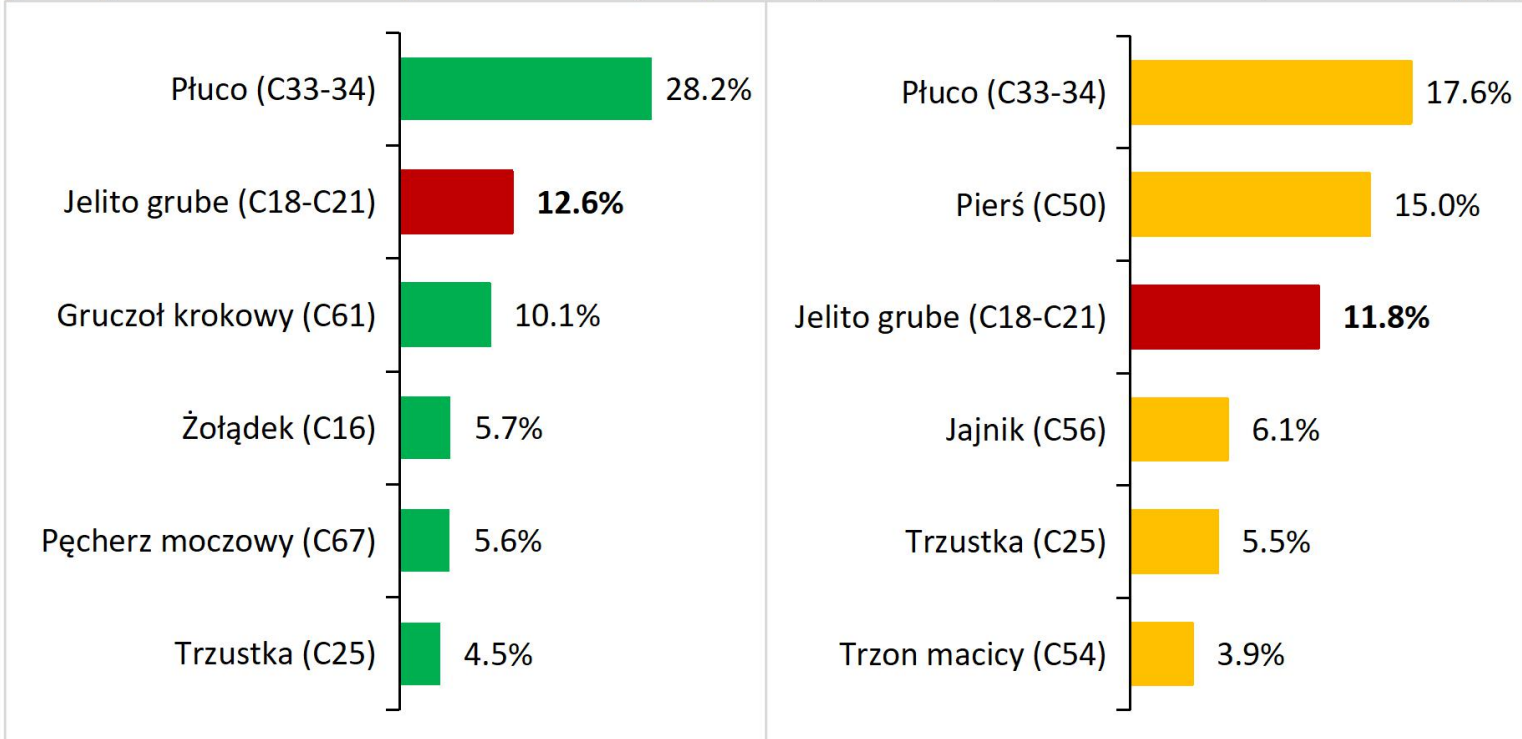

Rycina 6. Struktura najczęściej rejestrowanych zgonów z powodu nowotworów złośliwych mężczyzn (po stronie lewej) i kobiet (po stronie prawej) w Polsce w 2018 roku - opracowanie własne na podstawie [3,4] 
Wśród rejestrowanych w Polsce zgonów z powodu nowotworów złośliwych jelita grubego, zarówno w populacji kobiet, jak i mężczyzn zdecydowanie przeważają zgony spowodowane nowotworami złośliwymi zlokalizowanymi w okrężnicy. Stanowiły one bowiem $60-70 \%$ zgonów z powodu nowotworów złośliwych jelita grubego odnotowanych w Polsce w latach 1999-2018. Zgony spowodowane nowotworami złośliwymi odbytnicy stanowią 25-30\% wszystkich zgonów z powodu nowotworów złośliwych jelita grubego u obu płci. Z kolei rak odbytu i kanału odbytu oraz rak zgięcia esiczo-odbytniczego są przyczyną około $8 \%$ ogółu zgonów spowodowanych nowotworami złośliwymi jelita grubego (ryc. 7) [4].

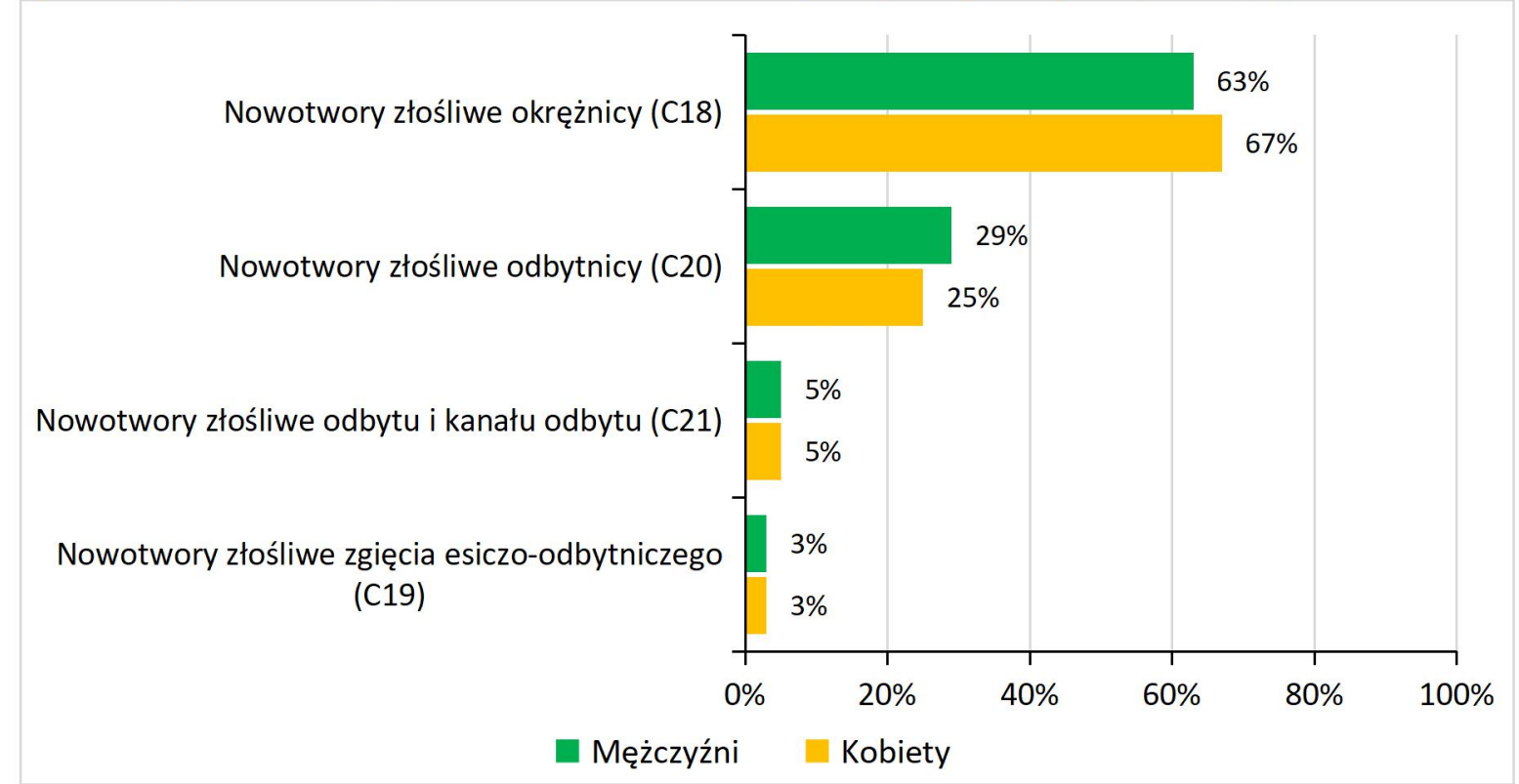

Rycina 7. Struktura zgonów z powodu nowotworów złośliwych jelita grubego (C18-C21) w Polsce w latach 1999-2018 - opracowanie własne na podstawie [4]

Niemal 90\% zgonów z powodu nowotworów złośliwych jelita grubego występuje po ukończeniu 60 roku życia. W męskiej populacji Polski najwięcej zgonów obserwuje się w ósmej dekadzie życia, natomiast u kobiet - w dziewiątej. Współczynniki umieralności z powodu nowotworów złośliwych jelita grubego wzrastają wraz z wiekiem począwszy od 50 roku życia u obu płci, przy czym dynamika wzrostu jest znacznie wyższa u mężczyzn niż u kobiet. Ryzyko zgonu z powodu raka jelita grubego, niezależnie od płci, jest najwyższe u osób po 80 roku życia. W 2018 roku surowe współczynniki umieralności z powodu nowotworów złośliwych jelita grubego dla kobiet i mężczyzn powyżej 80 roku życia wynosiły odpowiednio 194,1/100 000 i 383,4/100 000 (ryc. 8) [3-5]. 


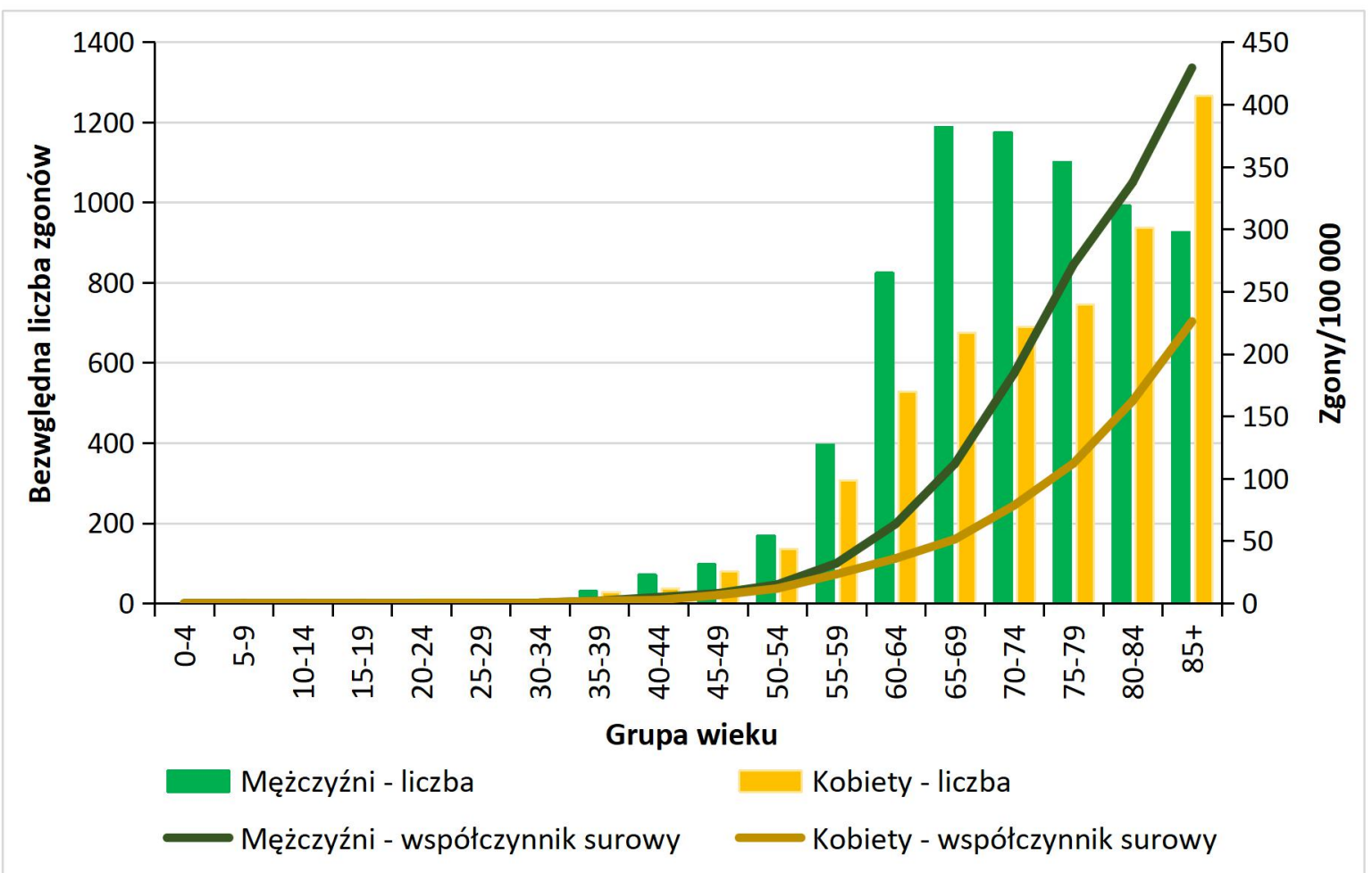

Rycina 8. Umieralność z powodu nowotworów złośliwych jelita grubego (C18-C21) w 5-letnich grupach wieku w Polsce w 2018 roku (na podstawie bezwzględnej liczby zgonów i wartości surowego współczynnika umieralności) - opracowanie własne na podstawie $[3,4]$

\section{Wskaźniki przeżyć}

Wśród pacjentów, u których zdiagnozowano raka jelita grubego w Polsce w latach 2000-2002 roczne wskaźniki przeżyć wynosiły 70,1\% u mężczyzn i 68,6\% u kobiet. W latach 2003-2005 zaobserwowano niewielką poprawę i roczne wskaźniki przeżyć wynosiły wówczas $72,4 \%$ dla mężczyzn i 70,8\% dla kobiet. Wskaźniki przeżyć 5-letnich również uległy poprawie - dla mężczyzn zdiagnozowanych w latach 2000-2002 wskaźnik ten wynosił 43,3\%, a dla tych, u których rozpoznanie miało miejsce w latach 2003-2005 - 47,6\%. Wskaźniki 5-letnich przeżyć dla kobiet, u których rozpoznano raka jelita grubego w latach 2000-2002 wynosiły 44,1\%, z kolei w latach 2003-2005 wskaźnik ten wynosił 49,1\%. Jednak mimo obserwowanej na przestrzeni lat rosnącej tendencji wskaźników 5-letnich przeżyć dla pacjentów chorych na raka jelita grubego, Polska pod tym względem zajmuje jedno $\mathrm{z}$ ostatnich miejsc w Europie. Odsetek względnych 5-letnich przeżyć dla pacjentów, u których rozpoznano raka jelita grubego w latach 2000-2007 w Polsce był niższy (niezależnie od płci i wieku) od średnich wartości europejskich tego wskaźnika* o około 10 punktów procentowych (ryc. 9) [5,12,13]. 


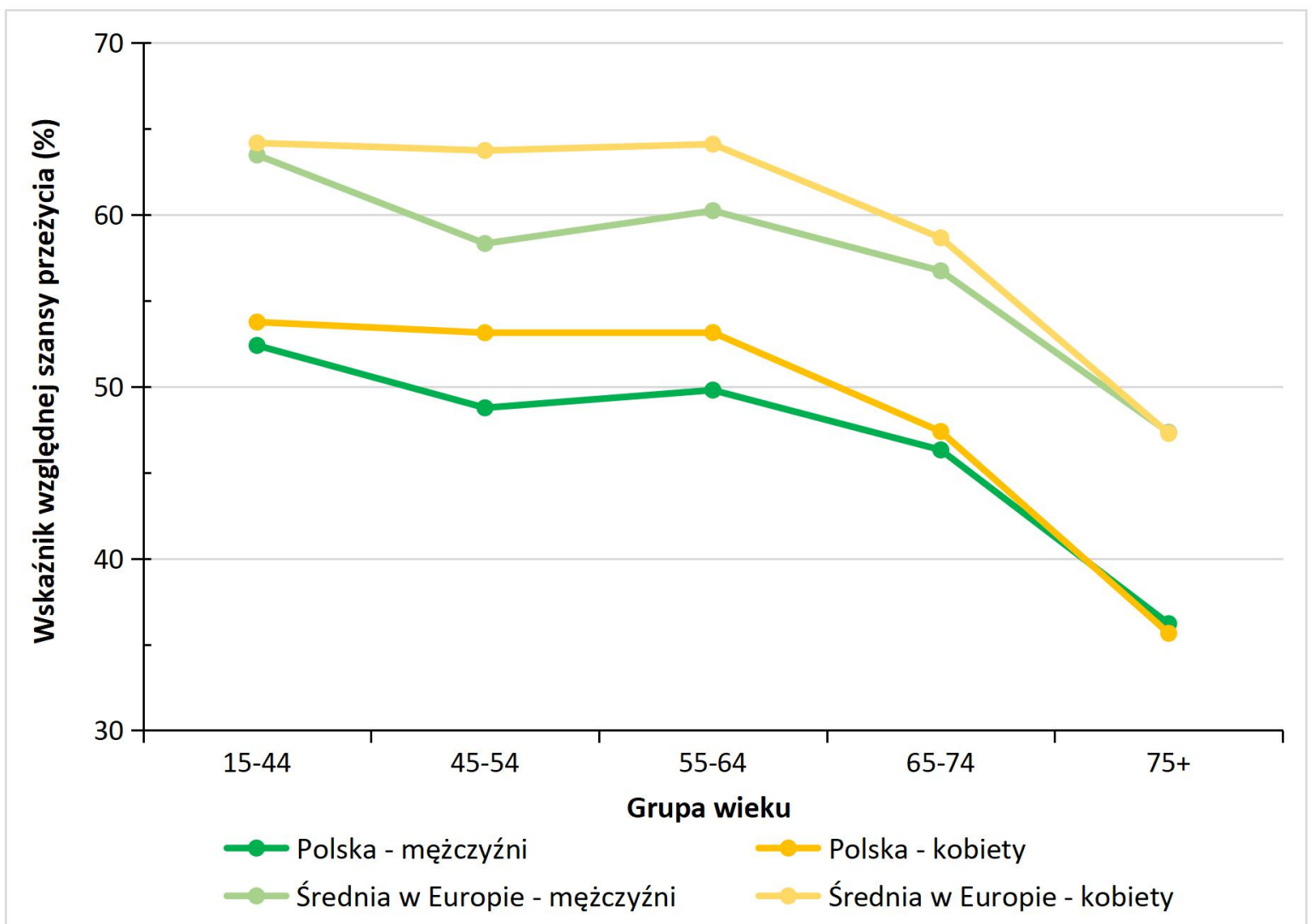

Rycina 9. Wskaźniki 5-letnich przeżyć względnych w poszczególnych grupach wieku dla kobiet i mężczyzn chorych na raka jelita grubego (C18-C21) zdiagnozowanych w latach 2000-2007 w Polsce a średnia wartość dla 26 krajów europejskich - opracowanie własne na podstawie $[12,13]$

* Średnia wartość wskaźników przeżyć pacjentów chorych na raka jelita grubego dla Europy została opracowana przez ECIS - European Cancer Information System na podstawie badania EUROCARE- 5, obejmującego dane pochodzące z 26 krajów europejskich, tj. Austria, Belgia, Bułgaria, Chorwacja, Czechy, Dania, Estonia, Finlandia, Francja, Hiszpania, Holandia, Irlandia, Islandia, Litwa, Łotwa, Malta, Niemcy, Norwegia, Polska, Portugalia, Słowacja, Słowenia, Szwajcaria, Szwecja, Wielka Brytania, Włochy [12,13]

\section{Prognozy}

Prognoza Krajowego Rejestru Nowotworów do 2025 roku wskazuje na kontynuację obserwowanych w Polsce od czterech dekad rosnących trendów zachorowalności na nowotwory złośliwe jelita grubego. Szybki wzrost zachorowalności dotyczy mężczyzn, w szczególności w średnim (45-64 lata) i starszym wieku (powyżej 65 roku życia). W populacji osób młodych (20-44 lata) przewiduje się stabilizację trendu zachorowalności na raka jelita grubego, natomiast wśród polskich kobiet należy spodziewać się niewielkiego wzrostu zachorowalności. Prognozy wskazują, iż niemal dwukrotnie wyższe u mężczyzn niż u kobiet wartości współczynników zachorowalności na raka jelita grubego utrzymają się do 2025 roku (ryc. 10) [14]. 

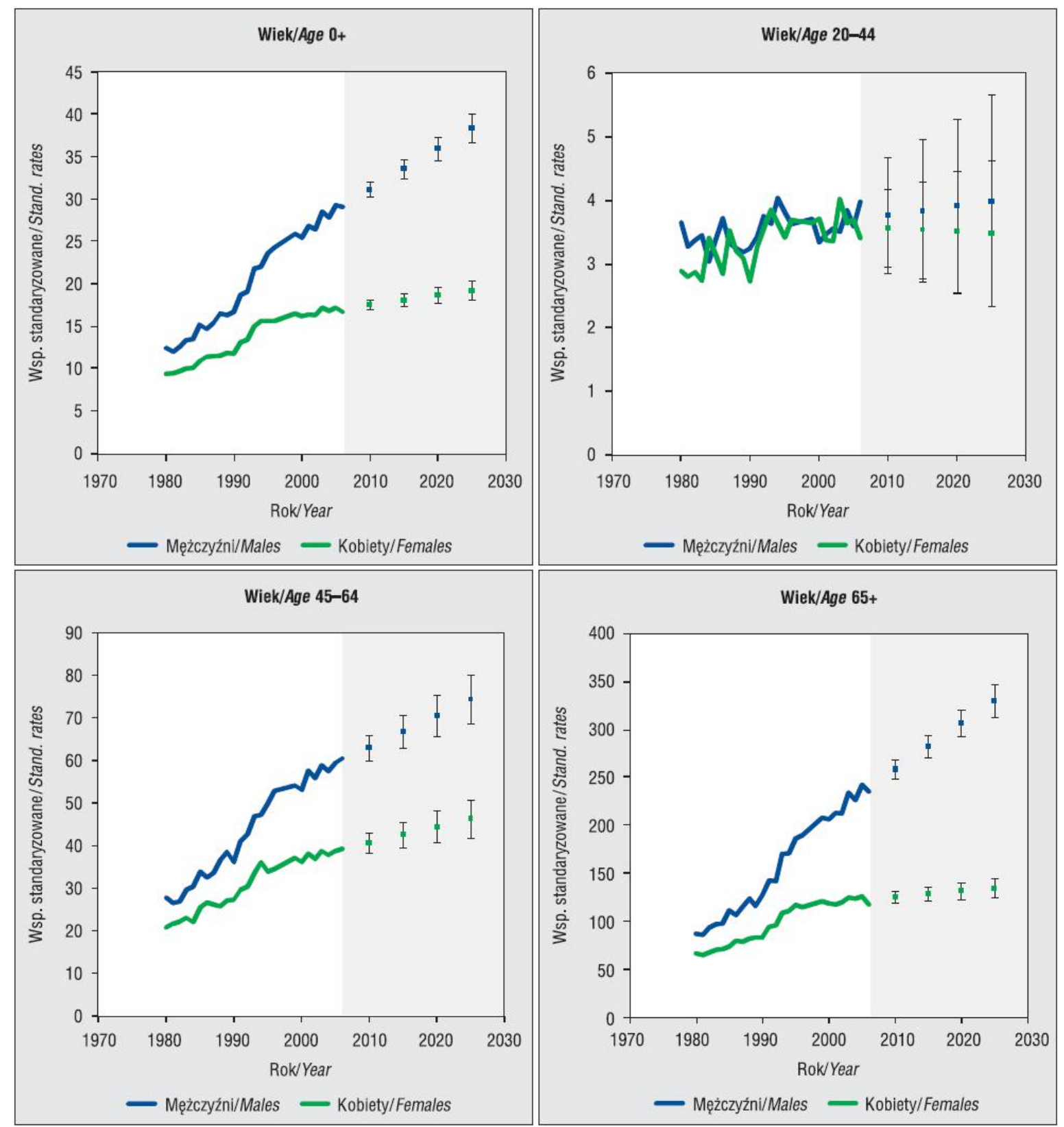

Rycina 10. Trendy zachorowalności na nowotwory złośliwe jelita grubego (C18-C21) w Polsce w latach 1980-2006 i prognoza do 2025 roku [14]

Według Krajowego Rejestru Nowotworów liczba nowych zachorowań na nowotwory złośliwe jelita grubego w 2025 roku w Polsce wyniesie blisko 24 600, przy czym niemal 15 500 przypadków wystąpi wśród mężczyzn. W populacji młodych dorosłych (20-44 lata) liczba zachorowań w stosunku do 2006 roku nie ulegnie znacznej zmianie. Niezależnie od płci, największego przyrostu liczby zachorowań należy spodziewać się wśród osób powyżej 65 roku życia. Prognozowana na 2025 rok całkowita liczba nowych zachorowań na raka jelita grubego jest o 75\% wyższa niż odnotowana w 2006 roku (ryc. 11) [14]. 


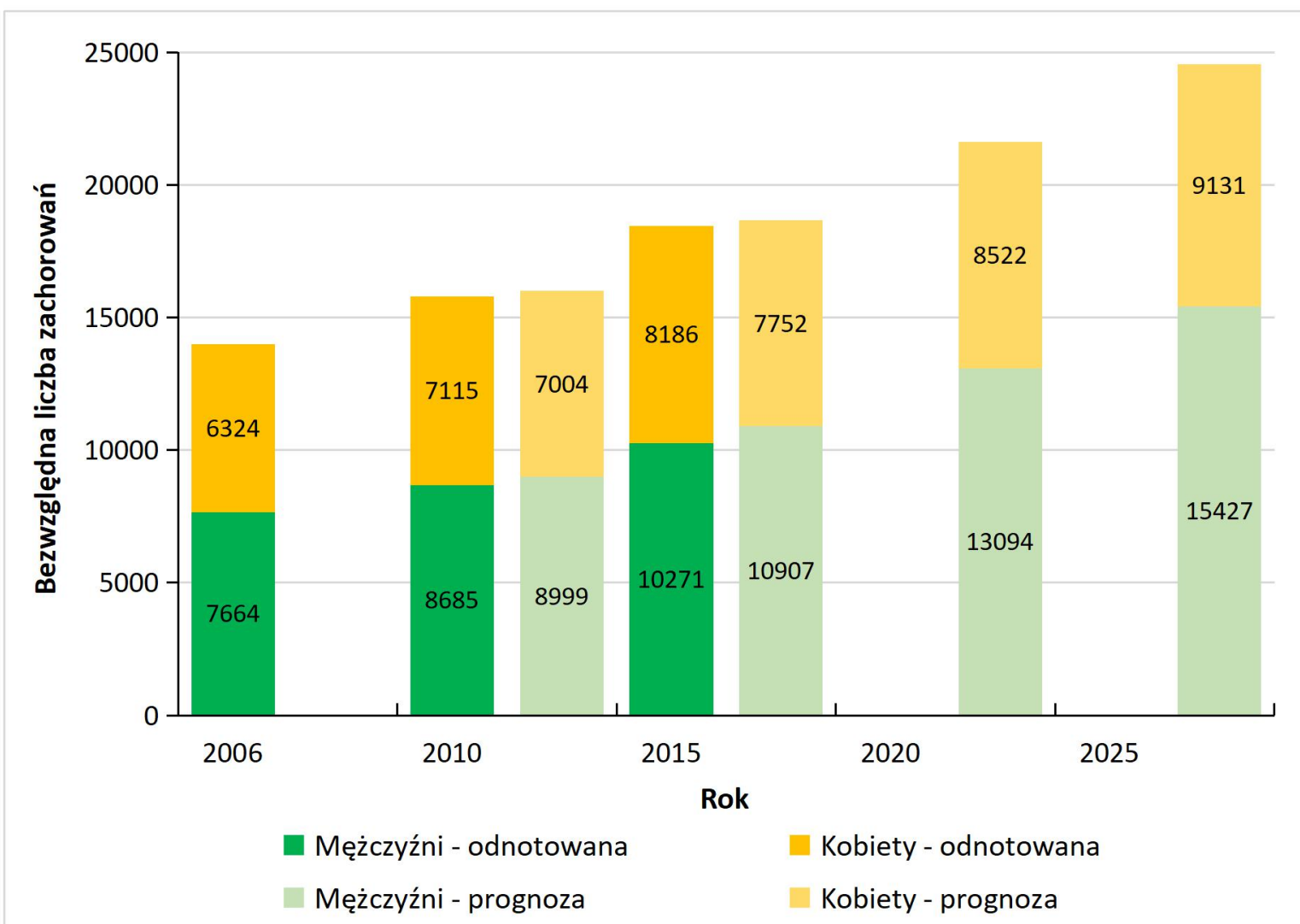

Rycina 11. Odnotowana liczba zachorowań na nowotwory złośliwe jelita grubego (C18-C21) w Polsce w latach 2006-2015 i prognoza do 2025 roku - opracowanie własne na podstawie $[4,14]$

Prognoza Krajowego Rejestru Nowotworów do 2025 roku przewiduje kontynuację obserwowanych obecnie w Polsce trendów umieralności z powodu nowotworów złośliwych jelita grubego. Szybki wzrost współczynników umieralności nastąpi wśród mężczyzn po 45 roku życia, przy czym największa dynamika wzrostu będzie zauważalna wśród mężczyzn w wieku 65 lat i więcej. Populację polskich kobiet do 2025 roku będzie charakteryzowało dalsze ograniczanie umieralności $\mathrm{z}$ powodu nowotworów złośliwych jelita grubego, przy czym wyraźnej tendencji spadkowej należy spodziewać się wśród kobiet młodych (20-44 lata) (ryc. 12) [14]. 

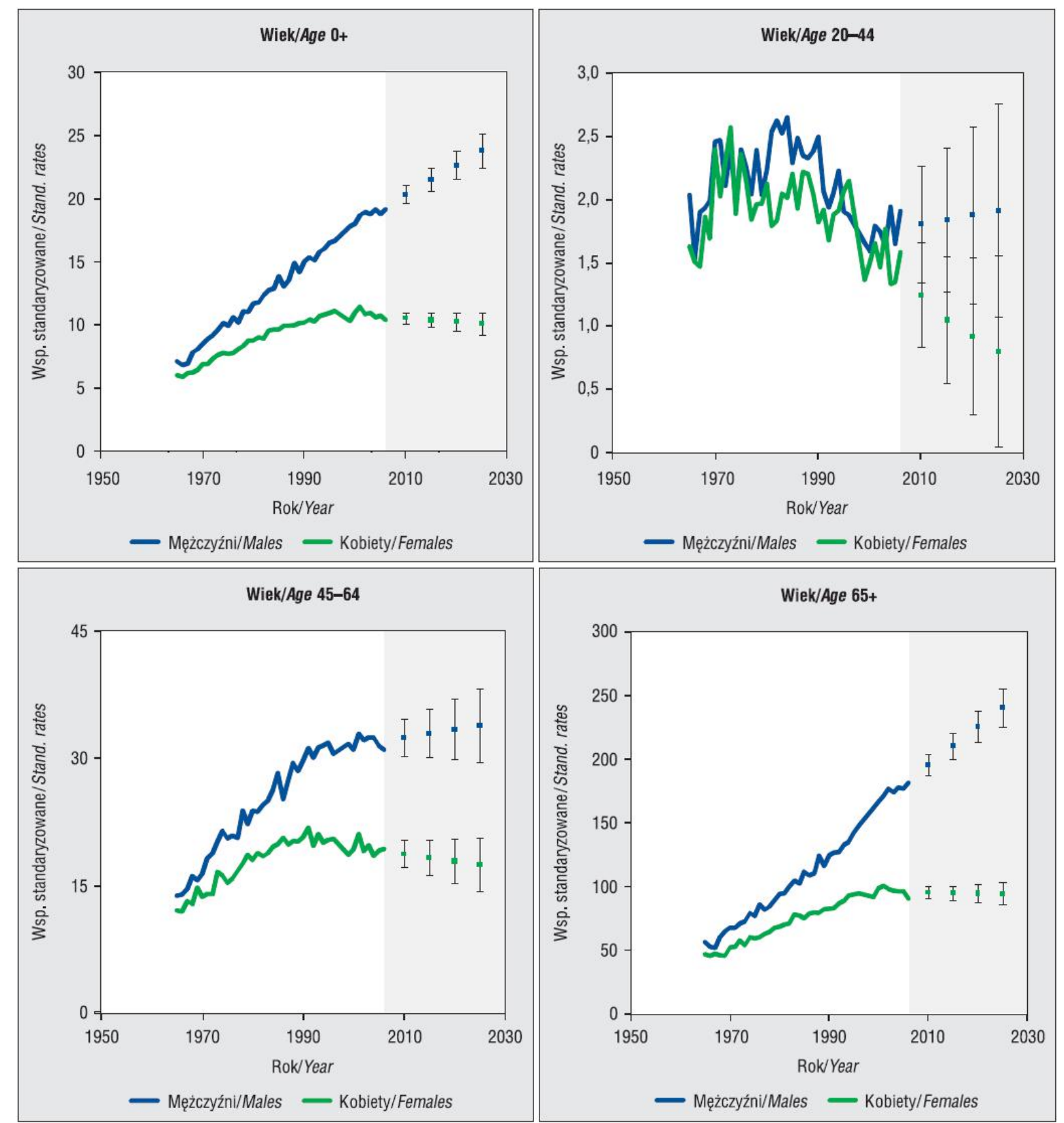

Rycina 12. Trendy umieralności z powodu nowotworów złośliwych jelita grubego (C18-C21) w Polsce w latach 1965-2006 i prognoza do 2025 roku [14]

Według szacunków epidemiologicznych Krajowego Rejestru Nowotworów liczba zarejestrowanych w 2025 roku zgonów z powodu nowotworów złośliwych jelita grubego w Polsce wyniesie blisko 16 700, z czego ponad 60\% wystąpi u mężczyzn. Przewiduje się, iż liczba zgonów mężczyzn w wieku 20-44 lata do 2025 roku utrzyma się na poziomie podobnym do obserwowanego w 2006 roku, natomiast wśród kobiet w tej grupie wiekowej należy spodziewać się spadku liczby zgonów. Wskazuje się, iż niezależnie od płci, do 2025 roku większość (ponad 80\%) zgonów z powodu nowotworów złośliwych jelita grubego wciąż będzie przypadać na najstarszą grupę wiekową (65 lat i więcej). Prognozowana na 2025 rok liczba zgonów mężczyzn $\mathrm{z}$ powodu nowotworów złośliwych jelita grubego jest niemal dwukrotnie wyższa niż odnotowana w 2006 roku, z kolei u kobiet przyrost liczby zgonów w stosunku do 2006 roku wyniesie około 40\% (ryc. 13) [14]. 


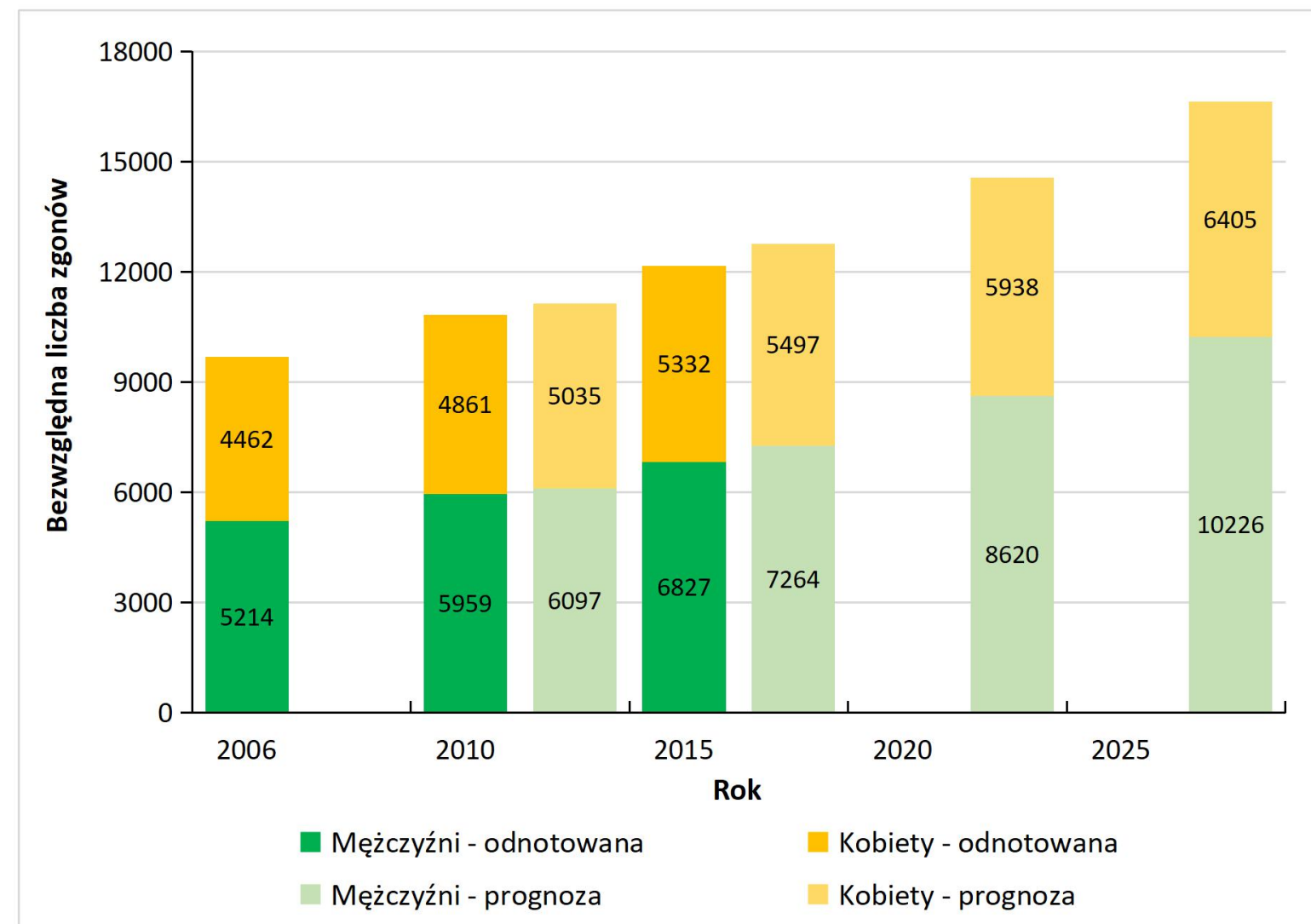

Rycina 13. Odnotowana liczba zgonów z powodu nowotworów złośliwych jelita grubego (C18-C21) w Polsce w latach 2006-2015 i prognoza do 2025 roku - opracowanie wtasne na podstawie $[4,14]$

\section{Wnioski}

Sytuacja epidemiologiczna raka jelita grubego w Polsce wskazuje na pilną konieczność upowszechnienia działań profilaktycznych w społeczeństwie - dotyczy to zwłaszcza badań przesiewowych. Kluczową kwestią, stanowiącą szansę na zmniejszenie współczynników zachorowalności i umieralności $\mathrm{z}$ powodu raka jelita grubego, a także zwiększenie przeżywalności chorych, jest kształtowanie świadomości prozdrowotnej społeczeństwa, co z kolei prowadzi do podejmowania właściwych zachowań zdrowotnych [7-10,15].

\section{Piśmiennictwo}

1. Didkowska J, Wojciechowska U, Czaderny K, Olasek P, Ciuba A. Nowotwory złośliwe w Polsce w 2017 roku. Warszawa: Centrum Onkologii - Instytut im. Marii Skłodowskiej-Curie; 2019.

2. Didkowska J, Wojciechowska U. Zachorowalność na nowotwory złośliwe w Polsce. W: Wojtyniak B, Goryński P, (red.). Sytuacja zdrowotna ludności Polski i jej uwarunkowania 2020. Warszawa: Narodowy Instytut Zdrowia Publicznego - Państwowy Zakład Higieny;2020: 247-267.

3. Wojciechowska U, Didkowska J, Michałek I, Olasek P, Ciuba A. Nowotwory złośliwe w Polsce w 2018 roku. Warszawa: Narodowy Instytut Onkologii im. Marii Skłodowskiej-Curie - Państwowy Instytut Badawczy; 2020.

4. Wojciechowska U, Didkowska J. Zachorowania i zgony na nowotwory złośliwe w Polsce. Krajowy Rejestr Nowotworów, Narodowy Instytut Onkologii im. Marii Skłodowskiej-Curie Państwowy Instytut Badawczy. http://onkologia.org.pl/raporty/ (dostęp: 2021.02.03). 
5. Wojciechowska U, Didkowska J. Zachorowania i zgony na nowotwory złośliwe w Polsce. Krajowy Rejestr Nowotworów, Narodowy Instytut Onkologii im. Marii Skłodowskiej-Curie Państwowy Instytut Badawczy.

http://onkologia.org.pl/nowotwory-zlosliwe-jelita-grubego-c18-21/ (dostęp: 2021.03.02).

6. Kubiak A, Kycler W, Trojanowski M. Epidemiologia i profilaktyka raka jelita grubego w Polsce. Probl Hig Epidemiol. 2014;95(3):636-642.

7. Wyrwicz L, Gryglewicz J, Chrostowski S, Domańska-Sadynica M, Ambroziewicz B. Sytuacja pacjenta $\mathrm{z}$ nowotworem jelita grubego w Polsce. Propozycje zmian. Warszawa: Fundacja Polska Koalicja Pacjentów Onkologicznych, Fundacja Wygrajmy Zdrowie; 2017.

8. Janiak M, Głowacka P, Kopeć A, Staśkiewicz A. Czynniki determinujące zgłaszalność na badania kolonoskopowe w Programie Badań Przesiewowych raka jelita grubego w Polsce. Gastroenterol Klin. 2016;8(4):142-151.

9. Kuprewicz A, Krajewska-Kułak E, Trochimowicz L. Wiedza na temat raka jelita grubego i preferowane zachowania zdrowotne mieszkańców miasta i wsi. Pielęg Chir Angiol. 2016;2:74-83.

10. Zyśk R, Wysocki P, Wyrwicz L. Rak jelita grubego - społeczne znaczenie zmian w zakresie epidemiologii i możliwości leczenia w Polsce. Onkol Prakt Klin. 2014;10(4):212-223. 11. Deptała A. Epidemiologia, wskaźniki przeżycia, środowiskowe uwarunkowania rozwoju raka jelita grubego. W: Deptała A, Wojtukiewicz MZ, (red.). Rak jelita grubego. Poznań: Termedia Wydawnictwa Medyczne;2018:13-17.

12. ECIS - European Cancer Information System. Estimates of survival, by country and cancer site. https://ecis.jrc.ec.europa.eu (dostęp: 2021.02.19).

13. De Angelis R, Sant M, Coleman MP, Francisci S, Baili P, Pierannunzio D, Trama A, Visser O, Brenner H, Ardanaz E, Bielska-Lasota M, Engholm G, Nennecke A, Siesling S, Berrino F, Capocaccia R. Cancer survival in Europe 1999-2007 by country and age: results of EUROCARE-5 - a population-based study. Lancet Oncol. 2014;15(1):23-34.

14. Didkowska J, Wojciechowska U, Zatoński W. Prognozy zachorowalności i umieralności na nowotwory złośliwe w Polsce do 2025 roku. Warszawa: Centrum Onkologii - Instytut im. Marii Skłodowskiej-Curie; 2009.

15. Chrobak-Bień JZ, Gawor A, Gąsiorowska A. Wiedza chorych na temat czynników ryzyka i profilaktyki raka jelita grubego. Piel Zdr Publ. 2016;6(3):187-195. 